\title{
PENINGKATAN KUALITAS MINYAK NILAM MELALUI PROSES ADSORPSI MENGGUNAKAN ADSORBEN $\gamma$-ALUMINA DENGAN SISTEM FLOW
}

\author{
Nur Fitria Nella Wati \\ Jurusan Ilmu Kimia, FMIPA Universitas Islam Indonesia, Yogyakarta
}

\begin{abstract}
Use of research studies have been carried $\gamma$ - alumina as an adsorbent in improving the quality of patchouli oil carried through the adsorption process flow system. Quality improvement based on analysis of patchouli oil quality parameters in accordance with SNI 06-2385-2006 about patchouli oil. These parameters include color, specific gravity, refractive index, acid value, the metal content of iron (Fe) and patchouli alcohol levels. Fe concentration measurements carried out using AAS instrument, and patchouli alcohol content measurement using GC instrument. Variations in the use of $\gamma$ - alumina adsorbents include weight variation is $5,10,15,20$ grams and variation of flow rate is 5 and 10 drops $/ \mathrm{min}$. Percent increase of patchouli alcohol occurred in the use of alumina as an adsorbent as much as 10 grams with a flow rate of 10 drops / min, increase of $27.6775 \%$. Moreover, it has the smallest Fe metal content is $11.2201 \mathrm{mg} / \mathrm{kg}$. Colour, specific gravity, refractive index, and levels of metals Fe after adsorption have met the quality standard patchouli oil.
\end{abstract}

Keyword: patchouli oil, adsorption, $\gamma$ - alumina, patchouli alcohol

\section{PENDAHULUAN}

Minyak atsiri atau yang disebut juga dengan essential oil, etherial oils atau volatile oils adalah komoditi ekstrak alami dari jenis tumbuhan yang berasal dari daun, bunga, kayu, biji-bijian bahkan putik bunga. Setidaknya ada 150 jenis minyak atsiri yang selama ini diperdagangkan di pasar internasional dan 40 jenis diantaranya dapat diproduksi di Indonesia (Manurung, 2010).

Minyak hasil penyulingan masihmengandung persenyawaan kompleks yang terbentuk dalam tumbuhan karena pengaruh air atau uap panas.Kandungan yang terdapat dalam minyak nilam meliputi, patchouli alcohol, eugenol, benzaldehyde, cinamic aldehyde, dan cadinene.Namun komponen yang paling menentukan kualitas minyak nilam adalah patchouli alcohol karena merupakan penciri utama (Santoso, 1990).Patchouli alcohol merupakan seskuiterpen alkohol yang dapat diisolasi dari minyak nilam. Tidak larut dalam air, larut dalam alkohol, eter atau pelarut organik yang lain. Mempunyai titik didih $280,37^{\circ} \mathrm{C}$ dan kristal yang terbentuk mempunyai titik lebur $56^{\circ} \mathrm{C}$.

Selama ini petani nilam hanya mampu menghasilkan minyak nilam dengan kandungan patchouli alcohol 26-28\%, sedangkan pabrik 
penyulingan dengan peralatan suling bahan baja anti karat mampu menghasilkan minyak nilam dengan kandungan patchouli alcohol 3135\%.Hasil minyak nilam ini diekspor dengan harga murah, padahal kandungan patchouli alcohol dalam minyak nilam dapat dimaksimalkan sampai $\quad 40-50 \% \quad$ (Santoso, 1990).Minyak nilam hasil produksi industri masih banyak mengandung senyawa-senyawa pengotor seperti kandungan logam $\mathrm{Fe}$, warna minyak nilam yang masih coklat keruh dan sebagainya. Sehingga diperlukan suatu proses pemurnian untuk meningkatkan kualitas dari minyak nilam tersebut.

Dalam penelitian ini, peningkatan kualitas minyak nilam akan dilakukan melalui proses adsorpsi menggunakan $\mathrm{Al}_{2} \mathrm{O}_{3}$ atau aluminium oksida ( $\gamma$-alumina) sebagai adsorben. Hal ini dikarenakan adsorpsi merupakan langkah yang cukup efektif untuk pemurnian melalui penyerapan senyawa-senyawa pengotor dalam minyak nilam ke dalam $\gamma$-alumina yang bertindak sebagai adsorben. $\gamma$ Alumina di pilih sebagai adsorben karena mempunyai permukaan yang aktif dan luas permukaan yang efektif dalam proses adsorpsi sehingga diperkirakan hasilnya akan lebih maksimal. $\gamma$-Alumina merupakan suatu molekul yang memiliki sistem pori serta situs-situs aktif pada permukaannya sehingga mempunyai kemampuan sebagai adsorben yang lebih baik dan maksimal dibandingkan dengan adsorben lain seperti arang aktif dan lempung.

Proses adsorpsi yang akan dilakukan untuk memurnikan minyak nilam adalah dengan sistem kontinyu (flow) menggunakan metode kromatografi kolom. Sistem ini dipilih untuk digunakan karena memiliki beberapa keunggulan yaitu dapat digunakan untuk analisis dan aplikasi preparative, untuk menentukan jumlah komponen campuran, dan untuk memisahkan dan purifikasi substansi. Pada dasarnya kromatografi kolom adalah pemisahan komponenkomponendalam sampel dengan cara mengalirkan sampel melewati suatukolom. Sampeldalam hal ini dibawa oleh carrier atau fase gerak (mobilephase). Sedangkan kolom berisi suatu bahan yang disebut fase diam(stationary phase) yang berfungsi memisahkan komponen-komponen sampel.Prinsip pemisahan kromatografi adsorpsi adalah kompetisi antara zatterlarut (sampel) dan fase gerak dengan permukaan fase diam. Kekuatanadsorpsi terutama tergantung sifat gugus fungsionalnya, dimana gugus-gugusfungsional ini menentukan tingkat kepolaran. Proses adsorpsi dipengaruhi olehkekuatan ikatan antara solut dan adsorben dan kekuatan untuk memisahkansolut dari adsorben.

Pembuatan atau isolasi patchouli alcohol dari minyak nilam pernah dilakukan oleh Hernani dan Wijaya (2002) dengan cara ekstraksi, 
menggunakan pelarut organik, kemurnian hasil isolasi yang diperoleh sebesar 82,1\%. Disamping itu, Yanyan et al. (2004) sudah melakukan penelitian isolasi patchouli alcohol dari minyak nilam melalui tiga tahapan yaitu metode destilasi terfraksi dengan tekanan rendah, dilanjutkan dengan ekstraksi dengan larutan $\mathrm{NaOH} 1 \mathrm{M}$, kemudian metode kromatografi cair vakum. Tahapan metode tersebut dapat meningkatkan kadar patchouli alcohol dari $35,77 \%$ menjadi sebesar $75,1 \%$.

Untuk mengatasi rendahnya kualitas minyak nilam yang berwarna gelap akibat kontaminasi dengan ion logam, dapat dilakukan dengan cara pengkelatan, namun dengan metode adsorpsi dengan menggunakan bentonit lebih menguntungkan. Pemurnian minyak cengkeh dengan bentonit sebagai penyerap (adsorben) logam terbaik daripada arang aktif dan zeolit. Pemurnian minyak cengkeh menggunakan zeolit dan bentonit mencapai 5\%, sedangkan dengan menggunakan arang aktif hanya mencapai 2,7\%. Kejernihan minyak dapat mencapai 75,58\% dengan bentonit. Secara fisik warna minyak yang dimurnikan dengan bentonit menjadi cokelat muda, sedangkan dengan arang aktif akan tetap hitam (Sariadi, 2012).

Penggunaan adsorben secara umum bertujuan untuk penyerapan (mengadsorpsi) komponen-komponen bahan pengotor dalam minyak atau senyawa trigliserida (Foletto et al.
2006). Beberapa penelitian yang berhubungan dengan proses adsorpsi telah dilakukan oleh beberapa peneliti, antara lain yaitu tentang proses adsorpsi minyak goreng bekas dengan adsorben zeolit (Widayat dan Haryani 2006), pemanfaatan zeolit alam Indonesia sebagai adsorben limbah cair dan media fluidasi dalam kolom fluidasi (Purwadi et al. 1998), pemucatan minyak biji kapas menggunakan bentonit teraktivasi asam (Foletto et al. 2006), adsorpsi klorofil menggunakan alumina (Mokaya et al. 1993), pemucatan minyak dari biji bunga matahari menggunakan bentonit (Topallar, 1998).

\section{METODE PENELITIAN}

Bahan-bahan yang digunakan dalam penelitian ini adalah minyak nilam dan alumina. Minyak nilam yang digunakan diperoleh dari perdagangan yang mempunyai kualitas rendah (tidak sesuai dengan SNI 062385-2006 tentang minyak nilam), $\gamma$ alumina,etanol 95\%, indikator penolpthalein, larutan kalium hidroksida (KOH), larutan asam oksalat $\left(\mathrm{H}_{2} \mathrm{C}_{2} \mathrm{O}_{4} \cdot 2 \mathrm{H}_{2} \mathrm{O}\right)$, asam nitrat pekat $\left(\mathrm{HNO}_{3}\right)$, akuades.

Peralatan yang digunakan dalam penelitian ini adalah sebagai berikut: piknometer, refraktometer, GC-MS merk Shimadzu tipe QP 2010 SE, AAS merk Perkin Elmer 5100 Pc Zeema. 
Adsorpsi minyak nilam dilakukan dengan mensirkulasikan minyak kedalam kolom adsorpsi yang berisi adsorben $\gamma$-alumina.Variasi yang digunakan dalam penelitian ini adalah variasi berat adsorben $(5,10,15$, dan 20 gram) dan variasi kecepatan laju alir minyak nilam (5 tetes/menit dan 10 tetes/menit).

Pengamatan yang dilakukan pada tahapan analisa adalah:penentuan warna, bobot jenis, indek bias, bilangan asam, konsenterasi $\mathrm{Fe}$ dan peningkatan persentasi kadar PA.

\section{HASIL DAN PEMBAHASAN}

Minyak nilam mengandung senyawapatchouli alkohol yang merupakan penyusun utama dalam minyak nilam, dan kadarnya mencapai 50-60\%. Patchouli alcohol merupakan senyawa yang tidak larut dalam air, larut dalam alkohol, eter atau pelarut organik yang lain. Mempunyai titik didih $280,37^{\circ} \mathrm{C}$ dan kristal yang terbentuk memiliki titik lelah
$56^{0}$ C.Pengamatan yang dilakukan pada tahapan analisa adalah: penentuan warna, bobot jenis, indek bias, bilangan asam, konsenterasi $\mathrm{Fe}$ dan peningkatan persentasi kadar PA.

\section{WARNA MINYAK NILAM}

Menurut SNI 06-2385-2006 tentang Minyak Nilam yang berlaku di Indonesia, warna minyak merupakan salah satu parameter yang sangat penting untuk menentukan mutu dari minyak nilam itu sendiri agar dapat dijual di pasar internasional dengan harga tinggi. Minyak nilam hasil penyulingan biasanya terlihat berwarna gelap akibat kontaminasi dari logam $\mathrm{Fe}$ dan $\mathrm{Cu}$. Hal ini akan berpengaruh terhadap sifat fisika kimia dari minyak nilam. Selain itu, minyak yang berwarna gelap dapat menyebabkan rendahnya harga minyak sehingga tidak dapat diekspor karena bermutu rendah dan tidak memenuhi SNI.Warna minyak yang baik menurut SNI adalah kuning muda - coklat kemerahan.

Tabel 1. Perubahan warna minyak nilam hasil adsorpsi

\begin{tabular}{|c|c|c|c|}
\hline $\begin{array}{c}\text { Minyak } \\
\text { Sebelum } \\
\text { Adsorpsi }\end{array}$ & \multirow{2}{*}{$\begin{array}{c}\text { Berat } \\
\text { Adsorben }\end{array}$} & \multicolumn{2}{|c|}{ Warna } \\
\cline { 2 - 4 } & & $\begin{array}{c}\text { Laju Alir 5 } \\
\text { Tetes/Menit }\end{array}$ & $\begin{array}{c}\text { Laju Alir 10 } \\
\text { Tetes/Menit }\end{array}$ \\
\hline \multirow{4}{*}{$\begin{array}{c}\text { Coklat } \\
\text { keruh }\end{array}$} & 5 gram & - & $\begin{array}{c}\text { Coklat } \\
\text { kekuningan }\end{array}$ \\
\cline { 2 - 4 } & 10 gram & Kuning & Kuning \\
\cline { 2 - 4 } & 15 gram & - & Kuning \\
\cline { 2 - 4 } & 20 gram & Kuning jernih & Kuning jernih \\
\hline
\end{tabular}

Peningkatankejernihan tersebut kekeruhan pada minyak nilam dapat disebabkan karenay-alumina mempunyai sifat mudah menyerap air sehinggaair yang dapat menyebabkan terserap, dan minyak menjadi jernih. Selain itu dengan berkurangnya logam dalam minyak, makaminyak menjadi 
lebih jernih, seperti yang dilaporkan Siewet al. (1994) dan Rossi et al. (2003). Peningkatan kecerahan dan kekuningan warnaminyak nilam disebabkan karena terjadinyapeningkatan luas permukaan adsorben yang semakin banyak. Dengan semakin luasnya permukaan adsorben maka komponen pengotor dalam minyak lebihbanyak terserap, sehingga kejernihan, kecerahan dankekuningan meningkat.

\section{BOBOT JENIS}

Bobot jenis minyak nilam sesuai SNI 06-2385-2006 harus berada pada rentang 0,950 - 0,975. Minyak nilam sebelum dan sesudah di adsorpsi memiliki bobot jenis seperti yang ditunjukkan pada Tabel berikut :

Tabel 2.Bobot jenis minyak nilam yang dihasilkan dari proses adsorpsi

\begin{tabular}{|c|c|c|c|}
\hline \multirow{2}{*}{$\begin{array}{c}\text { Minyak } \\
\text { Sebelum } \\
\text { Adsorpsi }\end{array}$} & \multirow{2}{*}{$\begin{array}{c}\text { Berat } \\
\text { Adsorben }\end{array}$} & \multicolumn{2}{|c|}{ Bobot Jenis } \\
\cline { 3 - 4 } & \multirow{3}{*}{1,5432} & $\begin{array}{c}\text { Laju Alir 5 } \\
\text { Tetes/Menit }\end{array}$ & $\begin{array}{c}\text { Laju Alir 10 } \\
\text { Tetes/Menit }\end{array}$ \\
\cline { 2 - 4 } & 10 gram & - & 1,2555 \\
\cline { 2 - 4 } & 15 gram & - & 0,9575 \\
\cline { 2 - 4 } & 20 gram & 0,9597 & 0,9718 \\
\hline
\end{tabular}

Hasil pengamatan tersebut menunjukkan bahwa semakin banyak penggunaan $\gamma$-alumina sebagai adsorben maka nilai bobot jenis minyak nilam semakin turun.Hal ini disebabkan oleh kandungan air yang mungkin masih terdapat dalam minyak nilam yang menyebabkan nilai bobot jenis dari minyak nilam menjadi tinggi semakin berkurang seiring bertambahnya jumlah adsorben yang digunakan.

Variasi berat adsorben maupun variasi laju alir minyak sama-sama memiliki pengaruh terhadap penurunan nilai bobot jenis minyak nilam hasil dari penelitian ini.Hasil terbaik menunjukkan bahwa semakin banyak adsorben yang digunakan dan semakin cepat laju alir minyak, maka nilai bobot jenis menjadi baik (memenuhi standar SNI). Hal ini terjadi karena semakin banyak adsorben yang digunakan maka akan semakin banyak pula pori-pori adsorben yang akan menyerap air dalam minyak. Semakin meningkatnya laju alir maka kapasitas adsorpsi dari $\gamma$-alumina juga akan semakin meningkat, karena dengan bertambahnya laju alir maka tekanan dari aliran akan bertambah sehingga akan meningkatkan interaksi senyawa yang terserap untuk masuk kedalam pori-pori adsorben.

\section{INDEKS BIAS}

Menurut SNI 06-2385-2006 tentang Minyak Nilam, indeks bias minyak nilam yang baik adalah antara 1,507 - 1,515.Indeks bias yang diperoleh dari minyak nilam sebelum dan sesudah diadsorpsi dapat ditunjukkan dalam Tabel 3 berikut. 
Tabel 3.Indeks bias minyak nilam sebelum dan sesudah di adsorpsi

\begin{tabular}{|c|c|c|c|}
\hline \multirow{2}{*}{$\begin{array}{l}\text { Minyak } \\
\text { Sebelum } \\
\text { Adsorpsi }\end{array}$} & \multirow{2}{*}{$\begin{array}{c}\text { Berat } \\
\text { Adsorben }\end{array}$} & \multicolumn{2}{|c|}{ Indeks Bias } \\
\hline & & $\begin{array}{l}\text { Laju Alir } 5 \\
\text { Tetes/Menit }\end{array}$ & $\begin{array}{l}\text { Laju Alir } 10 \\
\text { Tetes/Menit }\end{array}$ \\
\hline \multirow{4}{*}{1,5028} & 5 gram & - & 1,5048 \\
\hline & 10 gram & 1,5078 & 1,5078 \\
\hline & 15 gram & - & 1,5078 \\
\hline & 20 gram & 1,5088 & 1,5088 \\
\hline
\end{tabular}

Semakin banyak adsorben akan menyerap lebih banyak senyawa terpen yang dapat menurunkan nilai indeks bias minyak. Selain itu, ukuran partikel adsorben $\gamma$-alumina yang digunakan akan berpengaruh terhadap luas permukaan dalam menyerap ionion logam yang ada pada minyak, sehingga semakin kandungan ion logam berkurang mampu menaikkan indeks bias minyak nilam. Hasil dari penelitian ini menunjukkan perbedaan yang tidak signifikan.Hal ini mungkin karena jumlah senyawa terpen yang terdapat dalam minyak nilam memang berjumlah sedikit sehingga memiliki rantai karbon yang tidak begitu panjang dan jumlah ikatan rangkap yang sedikit.

\section{BILANGAN ASAM}

Menurut SNI, bilangan asam minyak nilam yang baik adalah maksimal bernilai 8. Hasil yang diperoleh dalam penentuan bilangan asam minyak nilam sebelum maupun sesudah di adsorpsi ditunjukkan dalam Tabel 4 berikut.

Tabel 4.Bilangan asam minyak nilam sebelum dan sesudah proses adsorpsi

\begin{tabular}{|c|c|c|c|}
\hline \multirow{2}{*}{$\begin{array}{l}\text { Minyak } \\
\text { Sebelum } \\
\text { Adsorpsi }\end{array}$} & \multirow{2}{*}{$\begin{array}{c}\text { Berat } \\
\text { Adsorben }\end{array}$} & \multicolumn{2}{|c|}{ Bilangan Asam } \\
\hline & & $\begin{array}{l}\text { Laju Alir } 5 \\
\text { Tetes/Menit }\end{array}$ & $\begin{array}{l}\text { Laju Alir } 10 \\
\text { Tetes/Menit }\end{array}$ \\
\hline \multirow{4}{*}{ 3,4194 } & 5 gram & - & 1,2823 \\
\hline & 10 gram & 1,2823 & 1,2823 \\
\hline & 15 gram & - & 0,8548 \\
\hline & 20 gram & 0,8548 & 0,8548 \\
\hline
\end{tabular}

Penurunan bilangan asam pada minyak. Karena proses oksidasi dalam penelitian ini menunjukkan pada minyak nilam ini terjadi oleh bahwa semakin berkurangnya salah satu komponen dari minyak kandungan logam seperti logam Fe nilam terdapat senyawa seskuiterpen dalam minyak nilam.Terdapatnya yang mempunyai ikatan rangkap, dan logam Fe pada minyak selain dengan adanya logam besi (Fe) ini menyebabkan warna minyak yang dapat berfungsi sebagai katalis menjadi cokelat (mengalami oksidasi) oksidasi yang menyebabkan ikatan dapat juga menaikkan bilangan asam rangkap pada senyawa tersebut 
terputus dan terbentuk suatu peroksida yang dapat menaikkan bilangan asam sehingga warna minyak nilam tersebut menjadi coklat tua.

\section{KANDUNGAN LOGAM Fe PADA MINYAK NILAM}

Logam Fe merupakan salah satu pengotor yang terdapat pada minyak nilam yang dapat menurunkan kualitas minyak.Salah satu nya menyebabkan minyak nilam berwarna keruh.Logam Fe ini biasanya berasal dari alat penyulingan minyak yang terbuat dari besi. Menurut SNI, kandungan logam Fe dalam minyak nilam adalah bernilai maksimal 25 $\mathrm{mg} / \mathrm{kg}$ (maksimal terdapat $25 \mathrm{mg}$ logam Fe dalam $1 \mathrm{~kg}$ minyak nilam).

Tabel 5.Hasil perhitungan kandungan logam Fe pada minyak nilam

\begin{tabular}{|c|c|c|c|}
\hline \multirow{2}{*}{$\begin{array}{l}\text { Minyak } \\
\text { Sebelum } \\
\text { Adsorpsi } \\
\text { (mg/kg) }\end{array}$} & \multirow{2}{*}{$\begin{array}{c}\text { Berat } \\
\text { Adsorben }(\gamma- \\
\text { alumina) }\end{array}$} & \multicolumn{2}{|c|}{ Kadar Fe (mg/kg) } \\
\hline & & $\begin{array}{l}\text { Laju Alir } 5 \\
\text { Tetes/Menit }\end{array}$ & $\begin{array}{l}\text { Laju Alir } 10 \\
\text { Tetes/Menit }\end{array}$ \\
\hline \multirow{4}{*}{42,4834} & 10 gram & 20,3255 & 11,2201 \\
\hline & Eks. $10 \mathrm{~g}$ & 25,6495 & - \\
\hline & 20 gram & 21,9953 & 15,4092 \\
\hline & Eks. $20 \mathrm{~g}$ & 23,0924 & - \\
\hline
\end{tabular}

Berkurangnya konsentrasi

logam $\mathrm{Fe}$ di dalam minyak nilam adalah gejala yang ditimbulkan akibat peristiwa adsorpsi.Sejumlah logam terjerap di permukaan adsorben $\gamma$ alumina. $\gamma$-alumina $\left(\mathrm{Al}_{2} \mathrm{O}_{3}\right)$ dengan luas area $\pm 250 \quad \mathrm{~m}^{2} / \mathrm{g}$ mampu menampung logam Fe. Interaksi antara logam Fe (adsorbat) dengan $\gamma$-alumina (adsorben) terjadi karena adanya gayavan der Waals dari bersifat nonpolar. Kemampuan adsorpsi dari adsorben $\gamma$-alumina bergantung pada distribusi gugus $-\mathrm{OH}$ tiap unit area adsorben (Oscik, 1982). Gugus -OH membuat permukaan adsorben bersifat polar. Akibatnya, ion logam besi $(\mathrm{Fe})$ dapat terjerap oleh gugus $-\mathrm{OH}$ pada permukaan dengan menghasilkan pertukaran kation.

Hasil pengukuran kadar Fe dalam minyak nilam dalam penelitian ini menunjukkan bahwa laju alir memiliki pengaruh yang cukup besar dalam penurunan kadar minyak nilam. Semakin meningkatnya laju alir, maka kapasitas adsorpsinya akan semakin meningkat karena adanya tekanan dari laju alir. Semakin besar laju alirnya, maka semakin semakin cepat waktu yang diperlukan adsorben untuk mencapai titik jenuh. Hal ini dapat dijelaskan karena pada laju alir yang lebih tinggi terjadi peningkatan tekanan yang mengakibatkan kontak dan interaksi antara ion logam Fe dan adsorben meningkat, selain itu meningkatnya laju alir akan memudahkan ion logam Fe masuk ke dalam pori-pori adsorben.

ANALISIS

PATCHOULI ALCOHOL

Sampel minyak nilam sebelum dan sesudah adsorpsi dianalisis 
kandungan patchouli alcohol nya diperoleh dari analisis sampel menggunakan kromatografi gas (GC). menggunakan GC dengan waktu Untuk mengetahui keberadaan retensi dari hasil analisis minyak nilam patchouli alcohol dalam sampel standar menggunakan GC-MS. Hal ini minyak nilam sebelum dan sesudah dapat dilakukan karena kondisi analisis proses adsorpsi dilakukan dengan cara $\quad$ yang sama pada alat GC dan GC-MS. membandingkan waktu retensi yang 


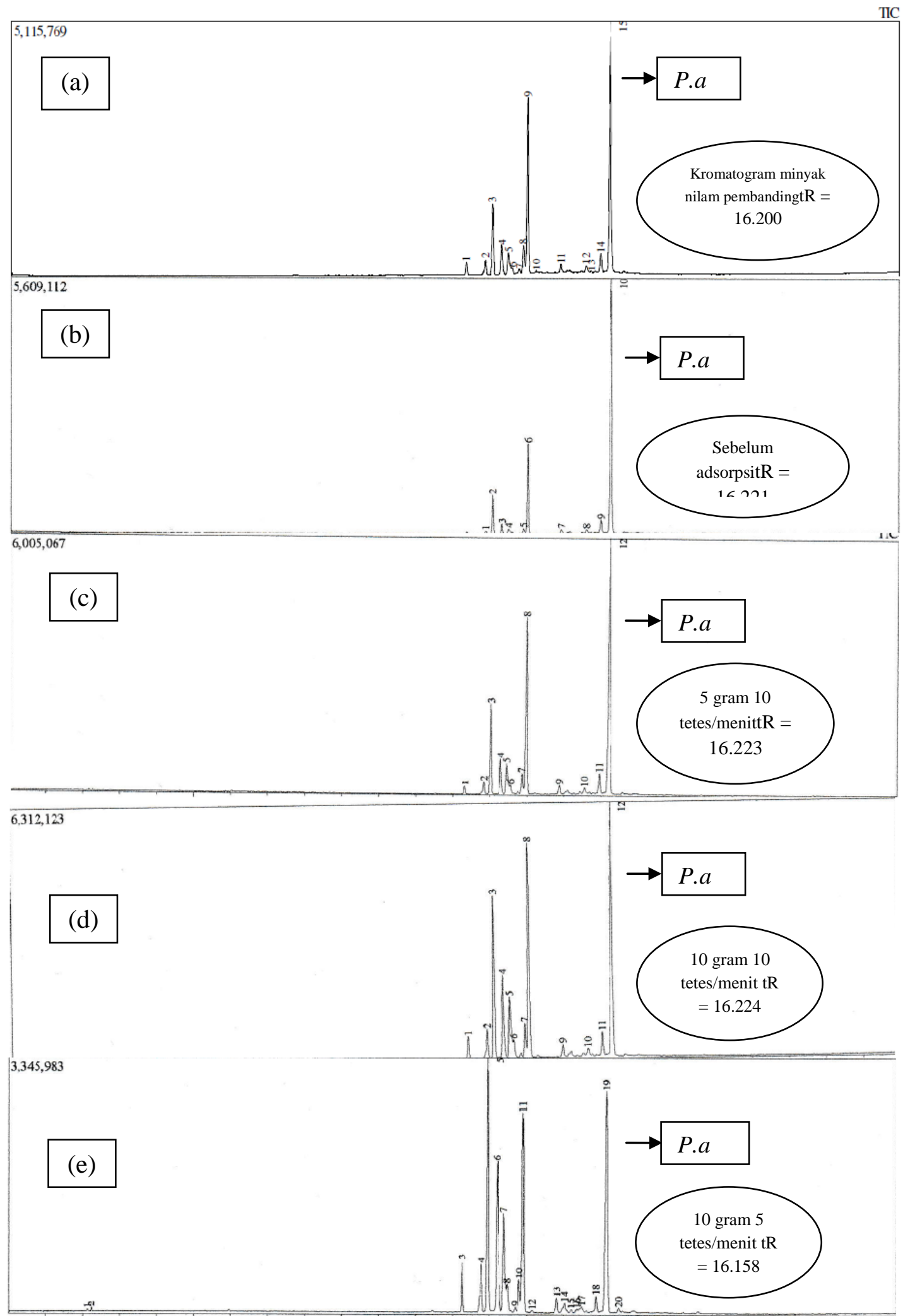




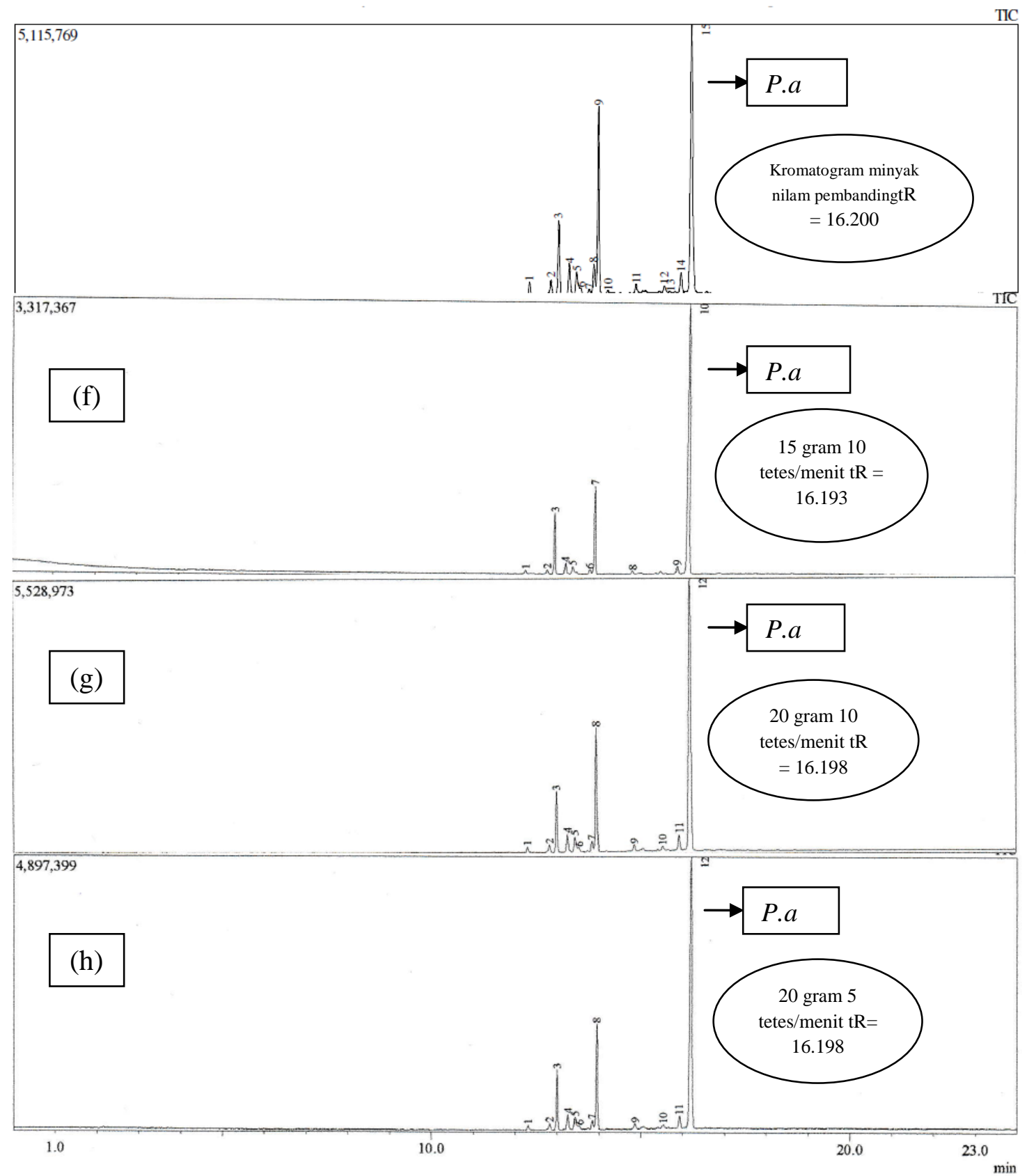

Gambar 1. Kromatogram minyak nilam: (a) pembanding; (b) sebelum adsorpsi; (c) hasil adsorpsi dengan 5 gram alumina 10 tetes/menit; (d) hasil adsorpsi dengan 10 gram alumina 10 tetes/menit; (e) hasil adsorpsi dengan 10 gram alumina 5 tetes/menit; (f) hasil adsorpsi dengan 15 gram alumina 10 tetes/menit; (g) hasil adsorpsi dengan 20 gram alumina 10 tetes/menit; (h) hasil adsorpsi dengan 20 gram alumina 5 tetes/menit. 
Tabel 5.Data perbandingan \% peningkatan patchouli alcohol sebelum dan sesudah adsorpsi

\begin{tabular}{|c|c|c|c|c|c|}
\hline \multirow{2}{*}{$\begin{array}{c}\text { Berat } \\
\text { adsorben }\end{array}$} & \multicolumn{3}{|c|}{ Luas permukaan } & \multicolumn{2}{c|}{ \% Peningkatan } \\
\cline { 2 - 6 } & $\begin{array}{c}\text { Sebelum } \\
\text { adsorpsi }\end{array}$ & $\begin{array}{c}\text { Laju alir 5 } \\
\text { tetes/menit }\end{array}$ & $\begin{array}{c}\text { Laju alir 10 } \\
\text { tetes/menit }\end{array}$ & $\begin{array}{c}\text { Laju alir 5 } \\
\text { tetes/menit }\end{array}$ & $\begin{array}{c}\text { Laju alir 10 } \\
\text { tetes/menit }\end{array}$ \\
\hline 0 gram & 21085685 & - & - & - & - \\
\hline 5 gram & 21085685 & - & 24717101 & - & $17,2222 \%$ \\
\hline 10 gram & 21085685 & 11235879 & 26921665 & $-46,7132 \%$ & $27,6775 \%$ \\
\hline 15 gram & 21085685 & - & 10673516 & - & $-49,3803 \%$ \\
\hline 20 gram & 21085685 & 17914669 & 21262514 & $-15,0387 \%$ & $0,8386 \%$ \\
\hline
\end{tabular}

$\gamma$-Alumina mempunyai ukuran yang cukup kecil sehingga memiliki luas permukaan yang besar seiring bertambahnya berat adsorben yang digunakan. Semakin kecil ukuran adsorben yang menyerap molekul adsorbet semakin banyak, semakin banyak massa adsorben yang digunakan menunjukkan semakin banyak luas permukaan adsorben yang dapat menyerap adsorbat dan semakin banyak pula pori-pori adsorben yang menyerap adsorbat. Jika semakin banyak adsorben $\gamma$-alumina yang digunakan maka luas permukaan aktif nya akan semakin banyak. Hal ini dapat menyebabkan penyerapan adsorbat (pengotor yang menutupi patchouli alcohol) semakin besar.Namun, jika terlalu banyak adsorben yang digunakan, kemungkinan patchouli alcohol justru ikut terserap kedalam permukaan adsorben.Sehingga pada penggunaan adsorben sebanyak 15 dan 20 gram, presentase patchouli alcohol mengalami penurunan.
Laju alir ternyata memiliki pengaruh terhadap kenaikan maupun penurunan persentase dari patchouli alcohol.Dari semua hasil yang diperoleh dari variasi yang dilakukan dalam penelitian ini ternyata laju alir 10 tetes/menit menghasilkan persentase kenaikan area patchouli alcohol yang lebih baik daripada laju alir 5 tetes/menit.Hal ini dikarenakan pada kecepatan tinggi meminimalisasi terjadinya kontak terlalu lama antara adsorben dan adsorbat sehingga dapat meningkatkan daya penetrasi antara minyak nilam dengan adsorben didalam kolom.

\section{KESIMPULAN}

$\gamma$-Alumina cukup efektif digunakan sebagai adsorben dalam upaya meningkatkan kualitas minyak nilam menggunakan sistem flow dalam penelitian ini dengan kondisi optimum 10 gram $\gamma$-alumina dengan laju alir 10 tetes/menit untuk sampel minyak nilam sebanyak $20 \mathrm{~mL}$ ( perbandingan minyak nilam : adsorben $=2: 1$ ). 


\section{DAFTAR PUSTAKA}

Manurung T. R. 2010. Peluang dan Hambatan dalam Peningkatan Ekspor Minyak Atsiri. WorkshopNasional Minyak Atsiri. Direktorat Jenderal IndustriKecil dan Menengah : 1-7.

Santoso, H. B., 1990, Nilam Bahan Industri Wewangian, Kanisius, Yogyakarta

Hernani dan S.K.S. Wijaya, 2002.Isolasi patchouli alkohol dari minyak nilam.Seminar Nasional IX Persada. Bogor. 10 hal

Yanyan, F.N. Achmad Zainuddin dan Dadan Sumiarsa, 2004.Peningkatan kadar patchouli alkohol dalam minyak nilam dan derivatisasi komponen minornya. Edisi khusus Teknologi Pengembangan Nilam Aceh.Pusat Penelitian dan Pengembang Perkebunan, Bogor.hal.72-78.

Sariadi, Pemurnian Minyak Nilam Dengan Proses AdsorpsiMenggunakan Bentonit, 2012, Jurusan Teknik KimiaPoliteknik Negeri Lhokseumawe, Jurnal Teknologi, Vol. 12, No. 2, Oktober 2012 : 100-104

Foletto, E.L., C. Volzone dan L.M. Porto. 2006. Clarification of Cottonseed Oil: How Structural Properties of Treated Bentonites by Acid Affect Bleaching Efficiency. Latin American Applied Research36 (2006) : 37-40.

Widayat, Suherman, dan K. Haryani. 2006. Optimasi Proses Adsorpsi Minyak Goreng Bekas Dengan Adsorben Zeolit Alam : Studi Pengurangan Bilangan Asam.Jurnal teknik gelagar.Semarang : Jurusan Teknik Kimia Fakultas Teknik UNDIP

Purwadi, B., Pariadi, Kamulyan B. dan Ariseno A. 1998. Pemanfaatan Zeolit Alam Indonesia sebagai Adsorben Limbah Cair dan Media Fluidasi dalam KolomFluidasi.Jurnal Penelitian Ilmu-Ilmu Teknik (Engineering), Volume 10/1(1998) : 13-25.

Mokaya, R., W. Jones, M.E. Davies dan M.E. Whittle. 1993. Chlorophyll Adsorption by Alumina Pillared Acid-Activated Clay. J. Am. Oil Chem. Soc., 70 (1993) :241244.

Topallar, Huseyin. 1998. The Adsorption Isotherms of the Bleaching of SunflowerSeed Oil.Tr. J. of Chemitry, 22 (1998) : 143-148.

Oscik, J. 1982. Adsorption.John Willey and Sons. New York. 